\title{
THE EFFECTS OF INTERACTIONS WITHIN COMMUNAL CONDITIONS IN IRAN AND ANATOLIA WITH IL KHĀNIDS OVER $13^{\mathrm{TH}}$ AND $14^{\mathrm{TH}}$ CENTURIES
}

\author{
Ghazal SOLTANI \\ İstanbul Technical University, Turkey \\ soltani@itu.edu.tr, ghazal.soltani@yahoo.com \\ https://orcid.org/0000-0002-9458-0821 \\ Davood REZAEI \\ d rezaei@znu.ac.ir \\ https://orcid.org/0000-0001-6510-6744
}

\begin{abstract}
Within the history of architecture, the sinewy movement of Mongols occurred between $13^{\text {th }}$ to $14^{\text {th }}$ centuries in Iran and Anatolia and also other regions such as Caucasus, Iraq, Syria, Egypt and Azerbaijan; but it did not take long time that new buildings and surroundings toward new culture in community came up. The significance of this article is to search and deal with the communal conditions of Iran and Anatolia through Il Khānid period, and get the results as the mutual effects by the existence of Il Khānids in these areas; besides, for better understanding of the artistic and architectural environment in Iran and Anatolia related to my $\mathrm{PhD}$ thesis through $13^{\text {th }}$ and $14^{\text {th }}$ centuries, the review of communal conditions as the topic of this article looked necessary through this article and also in my $\mathrm{PhD}$ thesis. Contemplating the methodology of this article goes through interpretive, analytical, historical and correlations methods by gathering information over library method; therefore, the points mentioned above and considering about the items such as culture, economic, religion, architectural life renewal and social environs in this era as in keywords and obtaining the consequential points of them through Il Khānid period in Iran and Anatolia will be the aim of this essay.
\end{abstract}

Keywords: Il Khānids, culture, Economic, Religion, Architectural renewal

\section{VE 14. YÜZYILLARDA İRAN VE ANADOLU'DAKİ TOPLUMSAL KOŞULLARIN ETKILEŞIMLERININ SONUÇLARI}

\section{ÖZ}

Mimarlık Tarihi içinde değerlendirildiğinde, 13. ve 14. yüzyıllarda başta İran ve Anadolu'da ve aynı zamanda Kafkasya, Irak, Suriye, Mısır ve Azerbaycan gibi diğer coğrafyalarda gerçekleşen güçlü Moğol hareketi, çok zaman geçmeden toplum içerisinde, yeni binaların ve yapılı çevrenin oluşmasını sağlayan yeni bir kültürü meydana getirmiştir. $\mathrm{Bu}$ makale İlhanlılar dönemi boyunca İran ve Anadolu'daki toplumsal koşulları araştırmayı ve İlhanlıların bu bölgelerdeki varlığının ortak sonuçlarını ortaya koymayı amaçlamaktadır. Ayrıca, doktora tezimle de ilişkili olarak, 13. ve 14. yüzy1llarda İran ve Anadolu'daki sanatsal ve mimari çevrenin daha iyi anlaşılabilmesi için bu çalışmada ve doktora tezimde de ele alındığı üzere toplumsal koşulların gözden geçirilmesi gerekli görülmektedir. Araştırma için kullanılan metodoloji kütüphanelerden bilgi toplamak aracılığıyla yorumlayıcı, analitik, tarihsel ve ilişki çözümleyici yöntemleri içermektedir. Bundan dolayı, yukarıda değinilen noktalarla birlikte, anahtar kelimeler arasında yer alan kültürel, ekonomik, dini, mimari hayattaki yenilenmeyi ve dönemin sosyal çevresini göz önünde bulundurarak İlhanlılar döneminin İran ve Anadolu'daki sonuçlarının elde edilmesi hedeflenmektedir.

Anahtar Kelimeler: İlhanlılar, Kültür, Ekonomi, Din, Mimari yenilenme

Submit Date: 10.01.2019, Acceptance Date: 25.03.2019, DOI NO: 10.7456/10902100/009 


\section{INTRODUCTION}

In the commencement of $13^{\text {th }}$ century, Genghis khan the leader of a nomadic tribes could control the people under his policy. Little later, the central Asia had become part of his territory as the Great Mongol States in 1206. Genghis Khan's successors also continued to broaden their leaderships via Mongol boundaries. In this case, they could conquer from the east of Asia through west. Thus, they could create internally autonomous territorial and political unit joined with others under a sovereign government by also with their traditional way of life, and rapidly adopted themselves with the administrative and judicial structures of other states for the control of their territories efficiently. After the invasion through Iran in 1219-1221 and after all devastations, new monuments began to rise from the ashes of the old towns. Before Il Khānids, the rulers of Seljuk dynasty governed Iran who had great power for almost one hundred and fifty years and after them by the end of $12^{\text {th }}$ century the Turkish Khwārazm Shāhs had the most authority who were in fact the vassals of Seljuks. After disagreement of Iranian monarch that did not accept the allowance for the merchants of Iran and Mongol empire to have commerce easily in the lands of two rulers, the Genghis Khan began a painful invasion through Iran (Aigle, 2008: 65 and Wilber, 1955: v-vii).

Afterwards, the Mongols became the ruler of Iran from 1256 and were called as Il Khānids. As a historical period, it might seem to end with the death of the last powerful Il Khānid ruler in 1335 (654$736^{\mathrm{A} . \mathrm{H}}$ ) and it prolonged throughout the life of local dynasties until 1400 by coming Tìmūr. There are three important points in the culture of Iran which had also influences in the architecture of Iran in different periods. The first point is the continuity, persistence and vigor of Iranian culture. An atmosphere with the most fertile characters for artistic activities increased the appeal of Iranian culture for the Mongol barbarians. The second point is the realm of architecture which the continuance of this technique as a vital one for Iranian culture is in the close correspondence in structures of the earlier Seljuk period and the monuments erected in Il Khānid period after an interval of more than fifty years during which was not practically building activity. The third point is the steady development and growth of architectural style in Iran, especially the characters of decorations had excess growth in Il Khānid period through their territories (Wilber, 1955: ix-xi).

In Anatolia, the weakness of the political power of the Seljuk state appeared between 1237-46 led the revolts and facilitated the Mongol invasion through this flat and they became the governors of Anatolia from 1240-1330. The vassal states of the Mongols were under the rule of Il Khānids established first in Iran as mentioned above. The fact that Anatolians did not take part in the building activities at first which were under the rule of Il Khānids from the year 1243 after Kösedağ war in 1243 were among the reasons why they had Buddhist rituals. Despite this fact, the construction activities have not stopped and have not weakened and later by changing to Islam, the Muslim ministers in Il Khānids with also Beyliks as very significant local dynasties in Anatolia have provided the continuity of zoning activities.

In fact, when the Seljuk dynasty lost legitimacy and many Turkmen principals formed in the absence of the administrative authority that had been formed (Sümer, 1970a: 75); Beyliks helped the Ghazan khan (Ghāzān Khan) to rebuild and reconfirm everything in its place. Even later, by the beginning of the $14^{\text {th }}$ century, Turkish Beyliks established in various regions in Anatolia and their independence become increased later even after the death of Abu Sa'id Bahadur Khan as the last ruler of Il Khānids after in 1335.

However, the economic and social situation of Anatolia affected the development activities which were by the based policies of the Seljuk state were mostly left to the Il Khānids at the beginning. On the other hand, the development activities to meet the needs of the people have been continued both in Iran and Anatolia. As a result of the Mongol invasion, many artifacts, monuments, communal conditions such as economic, cultures, social environment and related issues that were destroyed tried to be lifted again, huge construction activities were carried out and new cities within environments were established (Aytaç, 2017: iii and Blessing, 2014). 


\section{METHODOLOGY}

The methodology of research domain is in the realm of Iran and Anatolia and as quoted, the review of communal conditions and gain the important points about Il Khānid period through $13^{\text {th }}$ and $14^{\text {th }}$ centuries by way of chronological order and as the steps for entering to search and perceiving about the artistic and architectural environment in Iran and Anatolia but in another article looked necessary for writers in this article. Therefore, the tools for collecting data in this research is to view and record the information totally by taking notes with library method. The information analysis method is here based on the explanations made in each of these sections, various or sometimes mixed methods will be used to obtain the final result. Therefore, our approach to the advancement of this essay will include analytical, interpretive, historical and correlational methods.

\section{THE TERMS OF IRAN AND ANATOLIA UNDER IL KHĀNID AUTHORITY}

\section{Situation of Iran before the Dominance of Il Khānids}

In Iran, in the period of Seljuk dynasty which lasted almost 150 years (1037-1153/1194), in the middle of $12^{\text {th }}$ century, the period of decline began to happen and Shah Muhammad the ruler of Turkish Khwarazmian dynasty came over the rule after Seljuks which were their vassals in fact (Picture 1. and Picture 2.). The first of Il Khan warrior by the name of Genghis Khan who was not a normal striker in front of Shah Muhammad came through Iran with a tribe by the name of Tatar. Genghis Khan by the help and leading of Mongol people captured the northwest of China in 1205 and Kin Empire in 1211, he later reached to coast of yellow river and captured Beijing in 1215. Finally, he come through west in 1219 with a population of 700,000 people.

Genghis Khan had no desire to conquer Iran in his mind, but according to some writers about this issue and as mentioned above, they declare that Muhammad Shah disagrees with Genghis Khan envoys and therefore he moves his leaders through Iran. The city of Merv in Turkmenistan and Neishabour in Iran become part of Mongol conquests. Genghis Khan died in 1227. His successor Ogotai or Ögedei Khan renewed his campaigns through west with his Mongol commander by the name of Churamgun who beside Ogotai renovated the invasion through Khwarazmian in Iran. After all the cities are surrounded, life returns to normal but it has not been favorable for artistic activities at the same time which means between the years 1220-1270 there has not been constructed any building or any serious artistic works. After the death of Jala al-Din, son of Muhammad Shah Kharazmshah, the northwest regions of Iran as Ardebil, Diyarbakır in Turkey and north parts of Iraq are being conquered by Churamgun in the years of 1230-1231. Moreover, the continuance of Mongol battle with Seljuks in Anatolia extended which leaded to the conquest of the Mongols in Köse Dağ war in the year of 1243 near the Erzincan in Anatolia (Turkey of today). Likewise, the occupancy through Ismaili strongholds in the year of 1243 along the Caspian Sea began. In this regard, the summer capitals of Il Khānids became Ojan or Aujan which is today in (Bostan abad, Eastern Azerbaijan, Iran) and the Ararat foothills in (Armenia), and their winter capital was Aran plains in the western part of Caspian Sea (Caucasian lands) (Wilber, 1955:3-6). 


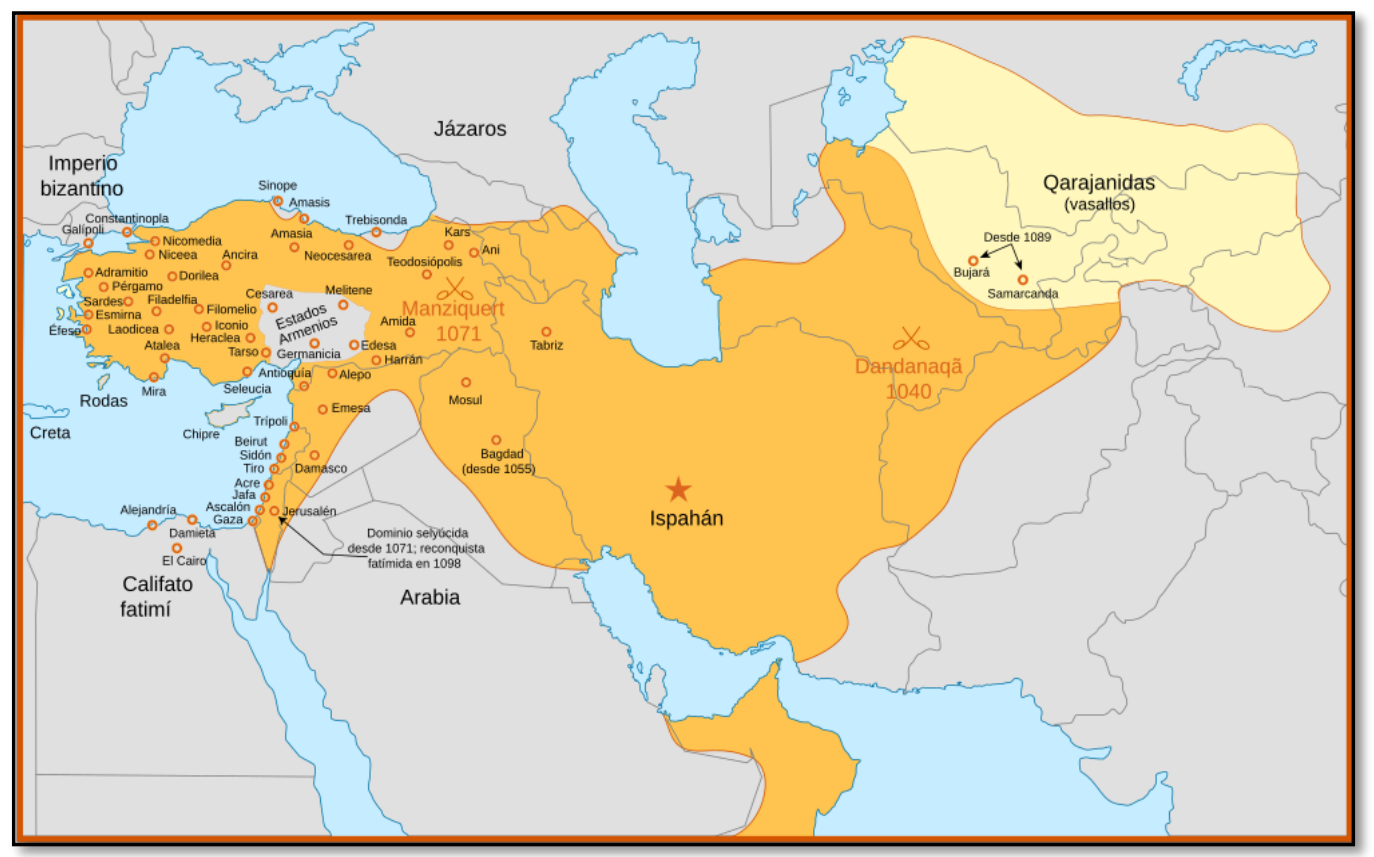

Picture 1. The Seljuk Empire

Reference:

https://upload.wikimedia.org/wikipedia/commons/thumb/d/d9/Seljuk_Empire_locator_mapes.svg/1000px-Seljuk_Empire_locator_map-es.svg.png

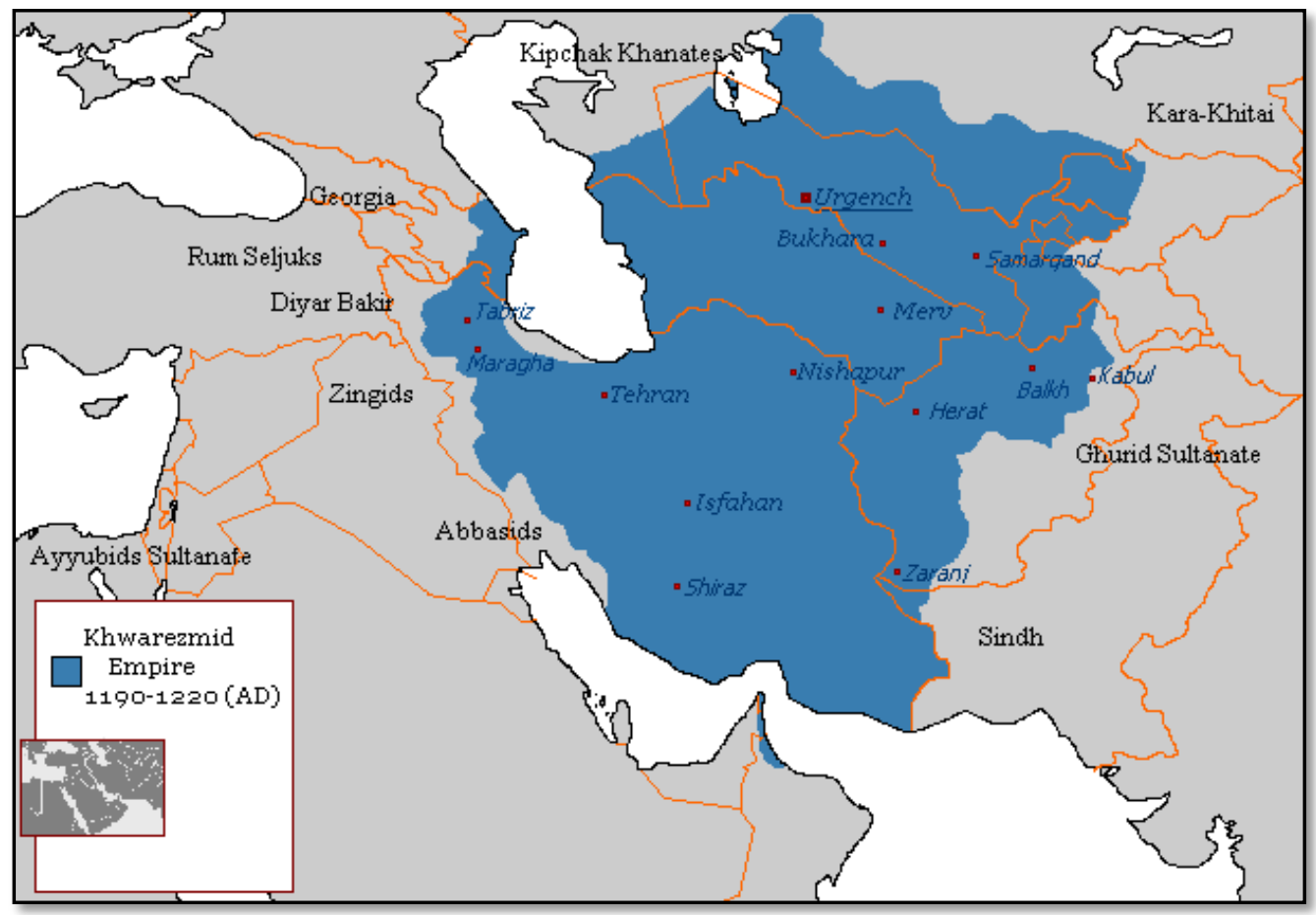

Picture 2. The Khwarazmian Empire in 1217

Reference: https://en.wikipedia.org/wiki/Khwarazmian_dynasty

The arrival of Seljuk dynasty impressively enlarged the number of familial groups in the country of Iran in $11^{\text {th }}$ century but without causing any vital change in its social and political organizations. The Seljuks were Muslims and quickly adapted themselves to Persian culture and society. In contrast, after them, the settling of Mongol tribes in Islamic Iran became an unmatched level in the county's 
chronological order and its growth which with respect to all the religions brought the country first under the control of a non-Muslim power for several decades (Aigle, 2008: 66); and later under the control of Muslim power mainly by the time of Ghazan Khan.

The Seljuks as the Turkish clans of nomads who established their domination by the year of 1055 and before the monarchy of Il Khānids had been amazed when they saw the cultural heritage of Iran and by settling in Iran became patrons of literary and arts. In the field of architecture, they encouraged for the erection of imposing structures which had this capability to give an exact character and the forms of earlier Iranian architecture and culture. Thus, this patronage served to formalize and give qualification to architecture types which otherwise were remained at lower levels (Wilber, 1955: ix).

\section{Situation of Anatolia before the Dominance of Il Khānids}

The Seljuk dynasty in Anatolia (1060-1307) who entered to Anatolia by the leading up of Tughril (Tuğrul) and Çağrı (brother of Tuğrul and father of Alp Arsalan or Muhammad bin Dawud Chaghri), and after the pressure of Karahanli (Karahanids) and Gazneliler (Ghaznavids) who could not overcome against Tuğrul and Çağrl, and when these two brothers gained their independence in the battle of Dandanaqan with Ghaznavids in 1040 in Khorasan part of Iran and could make expeditionary power later in 1071 in the battle of Manzikert in eastern part of Anatolia. Çağrı who saw the Byzantine Armenian and Georgian local governments were in conflict with each other and also with Byzantium, which in result there was not a strong administration and political unity in the region. Therefore, Çağrı by the established of Seljuk state in Khorasan part of northeast of Iran, continued his conquest towards Anatolia and could succeed them which Great Seljuk State was established consequently (Sevim, 1988:39-42). We see Anatolia in 1240 just before Mongol conquest in the Seljuq territory by the Maximum extent (Figure 1.).

From the first quarter of the $11^{\text {th }}$ century, the Seljuk Turks initiated to come to Anatolia for the purpose of discovery and for the purpose of settlement from the second half of the $11^{\text {th }}$ century. With the settlement policy of the Seljuks, Turkmen were leading to southeast and eastern part of Anatolia. While this situation prepared the grounds by the expeditions made by the Seljuks to Anatolia, it also caused the establishment of the Anatolian Seljuk state.

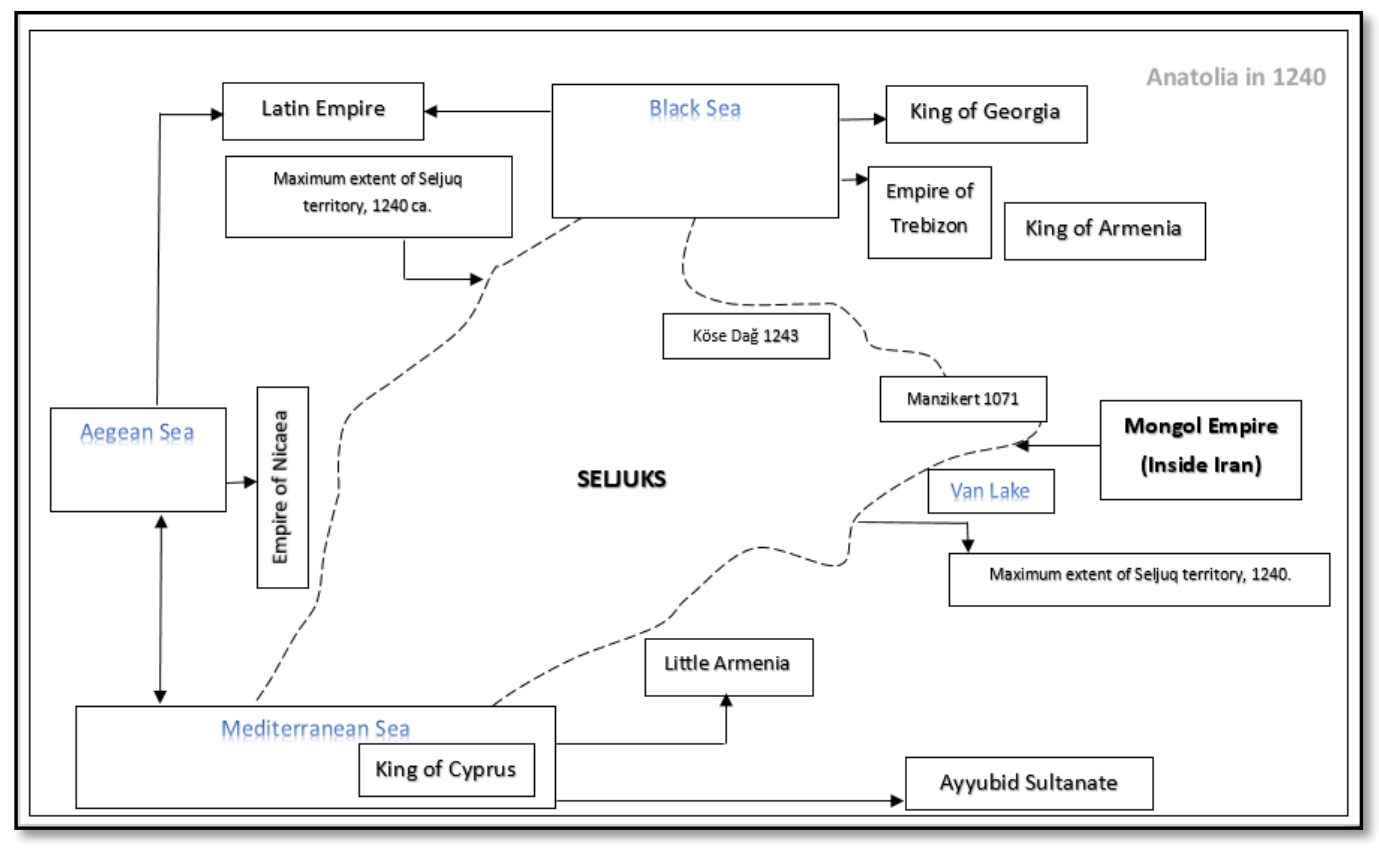

Figure 1. The Schematic of Anatolia in 1240 before Mongol conquest

Reference: Inferenced and Schemed by Ghazal Soltani from Mediterranean Mapping, Philip Schwartzberg, Blessing, P., 2014: xxi 
On these terms in Anatolia and later by the commencement of $13^{\text {th }}$ century when demographic movement started to take place and the new settlers coming to Anatolia, they tried to obtain new lands while they were also trying to organize politically and organize local governments. By occupying these new lands, the internal conflicts and crusades caused the division of political power in Anatolia. At the same time, architectural works meeting the needs of public were tried to be put forward. In Anatolia where the political authority of the Seljuk state was established in social, cultural and economical enrichment, the works were started to be built in a certain style and a unique identity of Seljuks was formed in art and architecture (Aytaç, 2017: 1-4).

The destabilization and economic weakness brought by the revolts due to the lack of political authority in the second half of the $13^{\text {th }}$ century between the years of 1250-1300 in Anatolia where the most prosperous period was in the time of Alā ad-Dīn Kayqubād I in the first half of the $13^{\text {th }}$ century between the years 1220-1237 and later was confronted the danger of Mongol especially in the battle of Köse Dağ in 1243. Kayqubād took political and military plans against the approaching danger but as mentioned before, he could not stand out in front of Mongol orders (Üremiş, 2005: 259). After the death of Alā ad-Dīn Kayqubād, Anatolia became open to the Mongolian invasion because of the political problems experienced and later as a result of killing the most important statesmen, there were fewer people in the Seljuk state with less management competence (Deniz, 2013: 27-47).

\section{Establishment of Il Khānid Dynasty over their Territories}

Mongolian name first was Mong-wu and Mong-wa as a small tribe among the tribes Şe-wei in $7^{\text {th }}$ century by the texts from China's T'ang dynasty. Two thousand years ago, this small tribe was in the environs of Tula Nehri up to the west and northwest of Mançurya or Manchuria, which the real Mongol tribes were living. In $6^{\text {th }}$ century, they were under the government of first Gök Türk and later Uygur. The formation of a state of Mongols was realized with Timuçin (Timuçin is the real name of Genghis Khan) (Özgüdenli, 2005: C. 30, 225). In 1195, after many tribes joined Timuçin, they formed a state by collecting the communities scattered as a result of long struggles. After Timuçin received the title of Genghis Khan in the congress gathered in 1206, he was in full control of Mongolia. By the Middle of $13^{\text {th }}$ century, the Mongol empire was too large to be ruled by the center states and the principalities of the Mongols in Asia (Özgüdenli, 2005: C. 30, 226) (Picture 3.).

The time when Mongol under Genghis Khan and his successors moved across the breadth of Asia, the armies, tribes and clans of Mongols gradually settled down far across from their almost homeland as Baikal Lake. They were travelling with their yurts as a dome like tent of felt or skins stretched over a framework of bent wood and easily transportable by horses. Wherever they found pasturage for their horses were settling and continuing their nomadic way of life; they also continued their nomadic way of life for somehow longtime after settling in Iran (Wilber, 1955: x). 


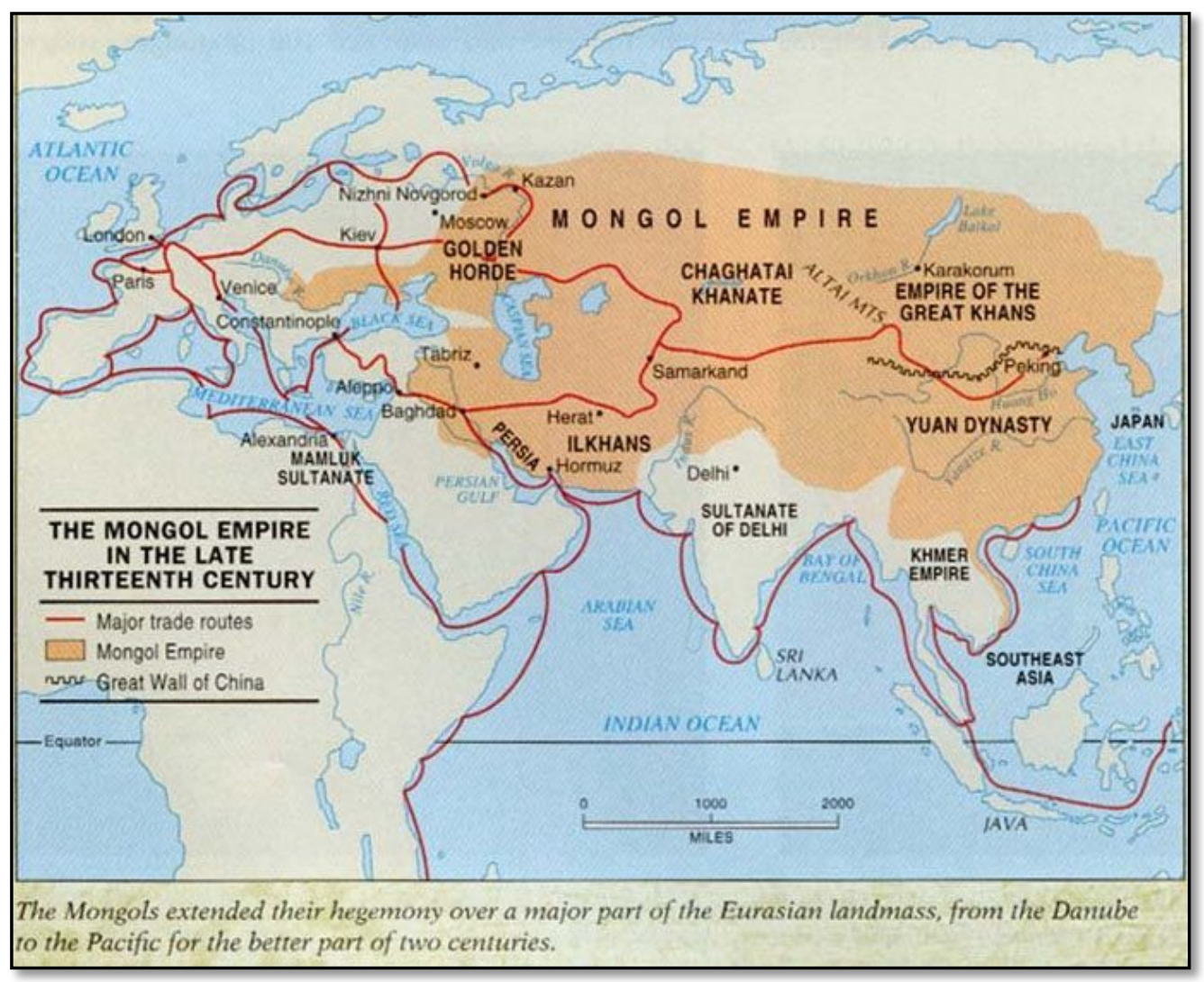

Picture 3. The Mongol Empire in the Late $13^{\text {th }}$ Century

Reference: https://www.quora.com

\section{Establishment of II Khānid Dynasty over the plateau of Iran}

Within Iran, the history of Il Khānid period (1256-1335) mostly comes from by the writings of historian men like Ata-Malik Juvayni and Rashid-al-Din Hamadani (Rashīd al-Dīn Faḍlullāh Hamadānī) who had great governmental organization under the Persian in Il Khānid era and therefore were associated to the Mongol authority very jointly (Aigle, 2008: 68). About Iran, the power and continuity of Iranian culture was a potent element in changing and trying to make progression over the centuries. From Long time ago the plateau of this region near the other regions was like a way also for the east and west of migratory and trade men groups. This character became also interesting for Mongols who was eager to have relation with Iran (Picture 4.).

Hulagu (Hülagû) Khan as the first one of Il Khānids in Iran who had been sent through west from Mongol empire was the grandson of Genghis Khan had a high position in the Mongolian system. He was also the brother of Khagan Mango and Kublai Khan. Hulagu in the year of 1245, after entering and crossing Iran's current borders resided in Torbat-e Heydarieh. His movement way is interesting because of the existence of buildings built during his successors. Hulagu on his way back ordered the ruins to be repaired and constructed as a result of previous attacks. Hulagu moves to the southern of Iran in 1257 and again continues to move along the way from to reach Hamadan and send the messenger to the Caliph's court from this place and advised that the fortifications of the Baghdad city be released, therefore the Caliph and Baghdad city be surrounded to Mongols. Hulagu could achieve to this aim in 1258 and the town and castle of Aleppo and later Damascus be seized in 1260 (Wilber, 1955: 7-8). 


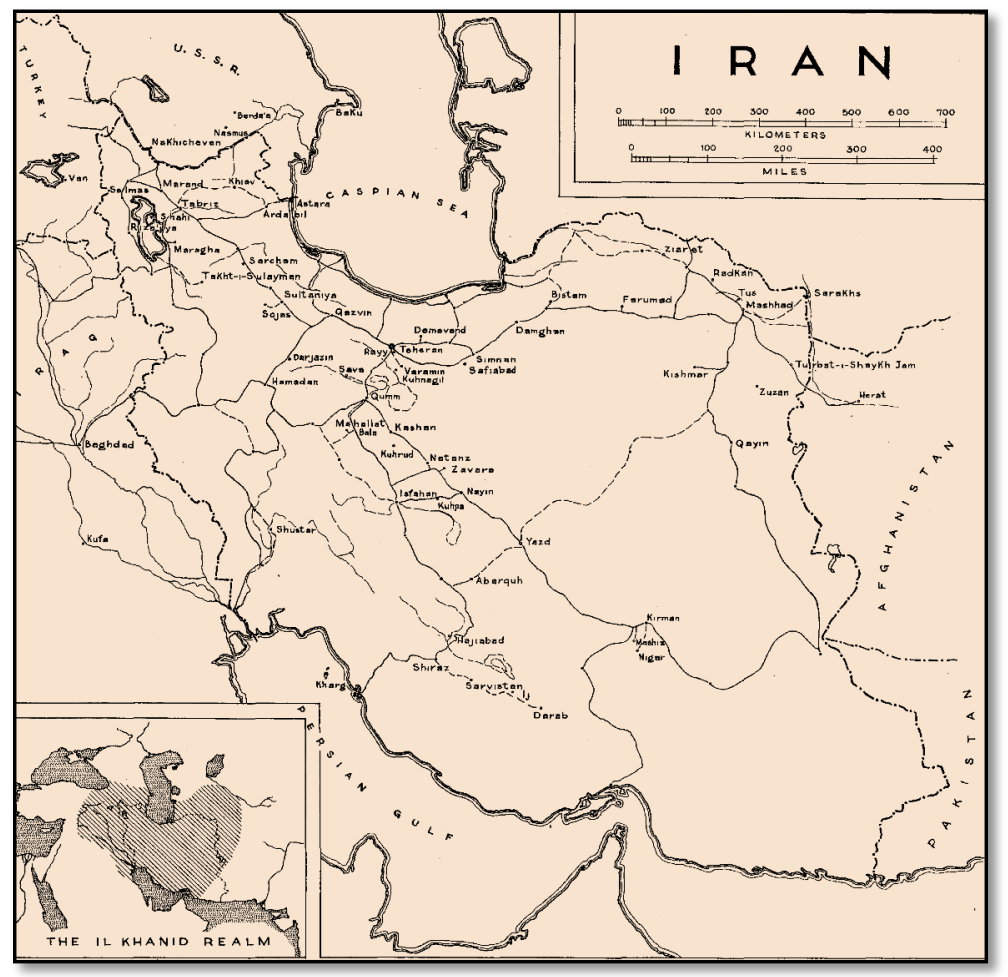

Picture 4. Sites of Il Khānid Period, Inset Shows the Extent of Il Khānid Realm Reference: Wilber, D. N., 1955

Abaqa Khan became the successor of his uncle Hulagu. After completing his country's work and conferring authority over the region, he continued to execute his father policies in area under his own jurisdiction. His chancellor Shams al-Din Juvayni who was vizier and sahib-divan or minister of finance under the three Mongol Il Khāns Hulagu, Abaqa and Tekudar from 1263 until 1285 was one of the prominent Iranian families. He set up his government in Tabriz but like Hulagu, he was spending the summer and winter as a tribal life. (Wilber, 1955: 11; Judith, 2006: 240). Later, Ghazan Khan came to the throne as another one of Hulagu's grandson by placing his capitals mainly in Maragheh and Soltaniyeh next to Tabriz in 1295. Ghazan Khan was more powerful than his predecessors and was a prominent person in any case. The huge Soltaniyeh tomb's architecture and construction continued in his time. His characters and accomplishments were recorded by one of the most famous ministers of Il Khānid era Rashid al-Din Hamadani (Rashīd al-Dīn Faḍlullāh Hamadānī). Similarly, Sa'd al-Din Zanjani (Sa'd al-Dīn Zanjanī) was one of other ministers who was elected in Ghazan khan's time and Ghazan Khan chose the name Mahmud for himself in Sa'd al-Din Zanjani's era. Sa'd al-Din also interested a lot in the administration of the country and the courts in his time never settled in Tabriz permanently. Likewise, in Mahmud Ghazan Khan (Maḥmūd Ghāzān Khan) time, the architecture was more in touch with Iranian culture and architecture, and the second significant work of his time was his paying attention to the culture of Islam and creation Islamic buildings (Wilber, 1955: 16-17).

\section{Establishment of II Khānid Dynasty over the plateau of Anatolia}

After the battle of Köse Dağ in 1243, it was inevitable for the Mongols to become vassals. Mongols who were the authority owners in the Anatolian administration began to show their influence in the buildings built after the Köse Dağ war. The municipal regulations continued at the beginning of $13^{\text {th }}$ century when Seljuk dynasty had not completely lost its power. However, over the time by weakness of Seljuks after war and in result the lack of authority and political controversy within the state caused the Seljuk dynasty to weaken. In Anatolia, Il Khānids became a state that ruled the territories they had taken under the Mongols (Picture 5. and Figure 2). 


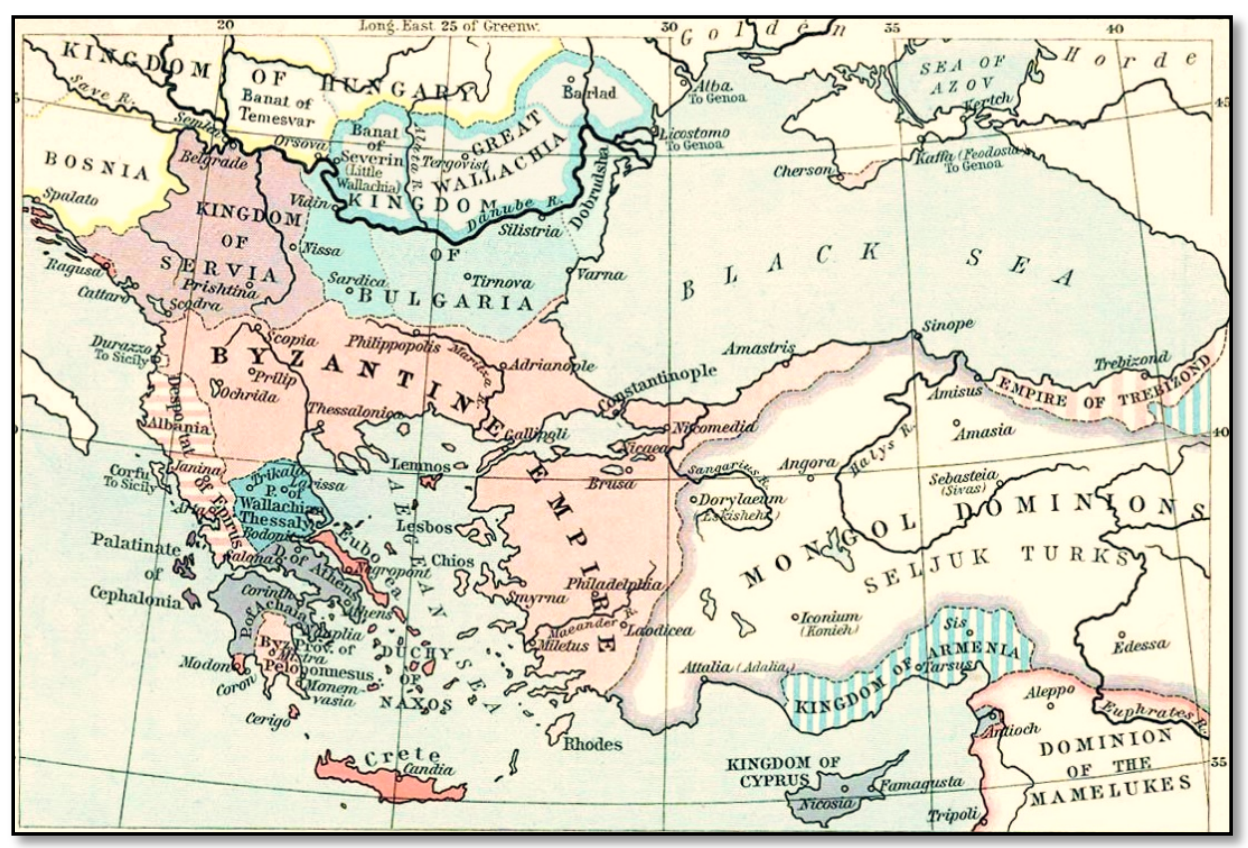

Picture 5. Anatolia around 1265

Reference:https://upload.wikimedia.org/wikipedia/commons/thumb/0/09/ShepherdByzempire1265.jp g/220px-ShepherdByzempire1265.jpg

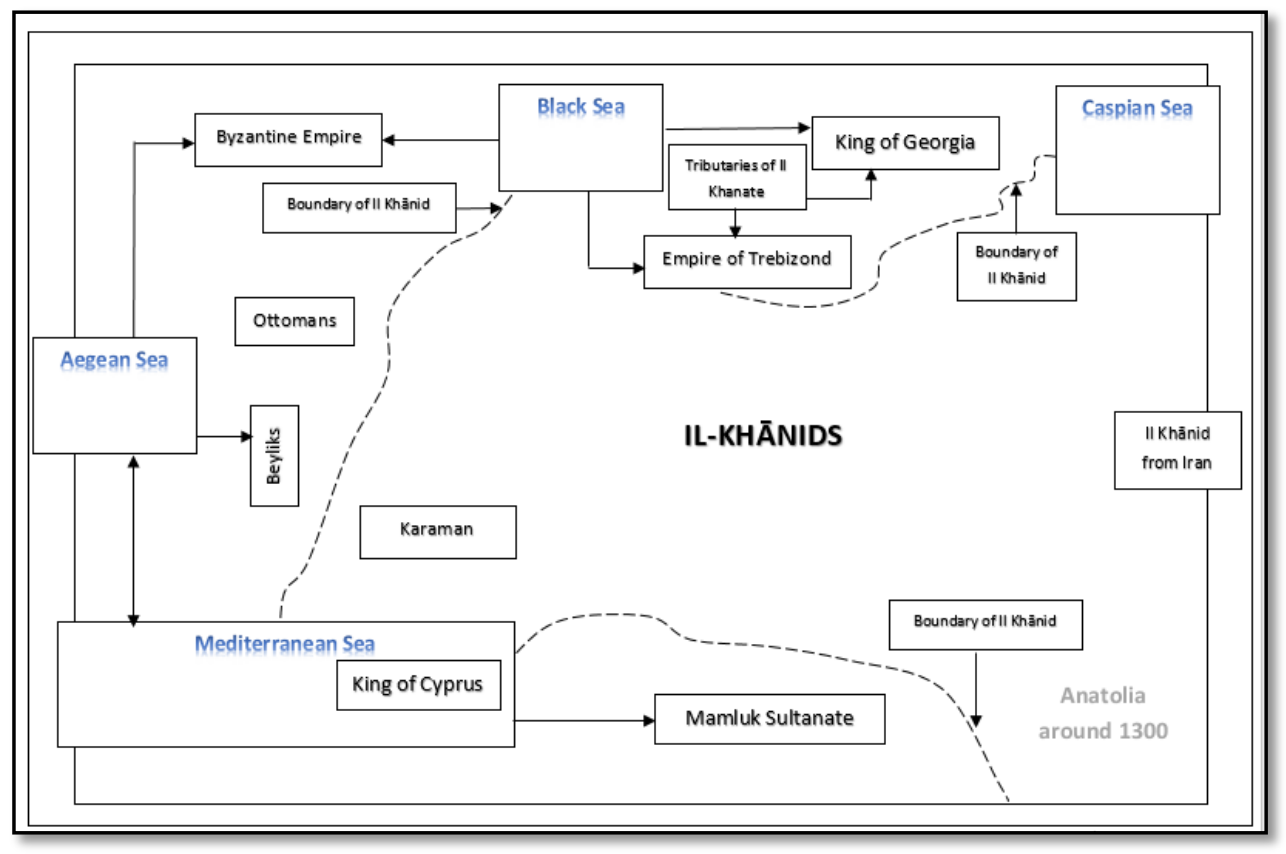

Figure 2. The Schematic of Anatolia around 1300

Reference: Inferenced and Schemed by Ghazal Soltani from Mediterranean Mapping, Philip Schwartzberg, Blessing, P., 2014: xxi

For reaching to a stylistic discipline for society and all related issues, zoning activities have been tried to be continued by the ministers due to the economic difficulties of the state even in architecture movement. In this case, the administration of Il Khānids started to continue to carry out the zoning activities of Seljuks between 1243 and 1260 as the expression of the state power for its existence.

Iranian ministers and orders were sent to Anatolia from the center of Il Khānid state in order to correct the deteriorated peace and economy by Il Khānids orders and ministers participated in these activities

Submit Date: 10.01.2019, Acceptance Date: 25.03.2019, DOI NO: 10.7456/10902100/009 
between 1260-1277. Ministers and orders sent to Anatolia to represent Il Khānid state administrations' contribution to authorize activities. Muin al-Din Sulayman Pervane as a high administrative position under Seljuks also negotiated about truce and tribute between Seljuqs and Mongols. Between 1277 and 1295, activities continued on a small scale. In the second part of 13th century in the year of 1295, Ghazan Khan, as one of the most important rulers who had accepted Islam, tried to conduct the Il Khānids as its best way. After Ghazan Khan (1295-1304) adopted Islam and proclaimed it as a state religion, the zoning activities in Anatolia were accelerated and these activities continued in Sultan Öljaitü era (1304-1316) and in Abu Sa'id Bahadur Khan (1317-1335). In other words, it was observed that everyone involved with the Sultan commands and the powers involved in the building activities from 1295 to 1335 .

After the government of Il Khānids, especially during the Ghazan Khan period, he repressed the revolts in Anatolia, made new financial regulations and donated each region a sponsor. However, due to the very high demanded taxes, people were having problem with paying and when these amounts to the treasury were insufficient to recover financials, Ghazan Khan was trying to improve the financial situations in Iran and also Anatolia and other territory parts by making reforms in the economic system. He also decided to rebuild the Il Khānid related regions which had been destroyed by the Mongols. Unfortunately, with Ghazan khan death in 1304, he could do half of the plans mentioned above (Erdem, 2003b: 57-70).

It can be seen that the construction activities in different building types of Il Khānid period in Anatolia continued until 1335 with smaller program constructions. However, both the damage and destruction caused by the Mongol army within environmental and natural factors have been had influences. For instance, some of the structures have lost their originality which have been tried to remake the ruins by the help of craftsmen who mostly have come from Iran to Anatolia. The constructions were comprising the works in different building types in Samsun, Amasya, Tokat, Sivas, Erzurum, Kırşehir, Niğde, Ankara, Konya, Divriği. Furthermore, by occupation of Baghdad in 1258 and having the center of Il Khānid state which is established in Iran in the year of 1256, Il Khānids had their three important capitals totally by the names of Maragheh or Marāgha (1256-1265), Tabriz (1265-1306) and Soltaniyeh (1306-1335).

\section{Social Conditions of Il Khānid Era through Iran and Anatolia}

The most important social issue in Il Khānid period which has had profound impact in the history of their territories in every respect has been the issue of religion. From what the history shows, the course of the religious issue is different from what is reasonably expected; and gaining the results in Mahmūd Ghāzān Khan, Öljaitü and Abu Sa'id Bahadur Khan's era do not have correspondence with severe deeds of Mongol and children of Genghis Khan. The softness and supportiveness of some of Il Khānids such as Ghazan Khan and Öljaitü throughout the Islam and the implementation of Islam's rules emerged and not having bias toward religious issues expanded throughout the community did not remain any pessimistic view toward Il Khānids. To judge fairly, the Mongol rulers against the negative characters that if they had, at least they had a very accepted personality which is un-prejudiced way of thinking on political, military and religious issues (Mortazavi, 1964: 17-20).

Several Il Khānids through Iran, Anatolia and other territories were Buddhists and several Christians and several Muslims. Il Khānid rulers who were religious in Buddhist and Christian are Hulagu KhanAbaqa Khan- Arghun Khan- Ghaykhatu Khan- Baydu Khan, and the ones who were Muslims are Ahmed Tekuder- Mahmud Ghazan Khan- Öljaitü (Muhammad Khodabandeh) and Abu Sa'id Bahadur Khan. Totally they were Shamanism, Nestorianism and Buddhist from 1256-1295 and they were Muslim from 1295 to 1335 (Mortazavi, 1964: 21-24). Their violence in the territorial regions was due to their normal and natural policies, not because of malice and revenge, even as the beliefs of Genghis Khan which represent the clear political, military and social goals for the people of his society stated that war and bloodshed are forbidden and the immunity and security of the people who were in the process of taking charge have been provided and we cannot find anything especial about the imposition of religion and beliefs. It has been said that the Mongol kings never considered severe 
verbal threats when they invited enemies to surrender and obey. They were telling as if you do not obey, then we know the thing that the God knows (Mortazavi, 1964:17-20).

When Hulagu as the first of Il Khānids in Iran and many of his nationals and companions settled in Azerbaijan between the years 1259-1265, Kublai Khan brother of Hulagu and Mango has become the ruler of China after the death of his brother Mango. Kublai khan divided the Mongol territory into four major parts and the Hulagu's part as mentioned was the central part of Iran, Khorasan part from Iran, Azerbaijan, Iraq, Georgia, Armenia and part of Asia Minor. Tabriz was named as the new capital and the concentration of Mongol power in Azerbaijan caused for the transfer of wealth, culture and civilization of the Khorasan as qualities for centuries to Azerbaijan for learning and renovating other parts like Khorasan, and Tabriz was given more honorable position than the former as the capital of the state. The destruction of the Caliphate's power stripped off the commercial importance of Baghdad and cities like Mosul; but in the journey of Marco Polo around 1300, trading had been done from Baghdad to India through Persian Gulf. Merchants and business representatives from independent Italian cities that had been settled on the coast of Syria for many years moved gradually into the continent of the Mongolian domination after receiving guidance and information from the messengers and priests. Hulagu, his courts and his citizens could no longer be seen as nomadic battalions and they could not be able any more to go other places so much and as soon as possible they were influenced by the new natural environment and the great civilization and the culture of locality. The Mongols were deeply affected by contact with Islamic and their new territories culture. The Mongol Yasa or the code laid down by Genghis Khan as a proper authority for controlling turbulent tribal units and dealing with such elemental problems as the ritual methods for sacrificing animals or retributive punishment for common crimes was scarcely adaptable to new situation, so interior divisions and the management of the country soon returned to the routine set down under the ancient Iranian system. Throughout the reign of Hulagu, it was well behaved with Christians, Georgian and Armenian historians mentioned as a lot of cases of this kind of behavior (Wilber, 1955: 8-9).

Hulagu and his people lived in the hottest and coldest days of the year in nomadic way of life and the most points of their interest such as Mughan, Barda or Berdaa, Alatagh, Aujan, Qarabagh were not far from Tabriz and reach to each of them was possible within the days. The place of attention for Hulagu was Maragheh which was especially suitable for him. The ground was flat and was irrigated by a small river and the mountains climate were cool enough and in front of it, there was a plain beside Urmia lake which was a great pasture for countless horses. The formation of such camps was undoubtedly the sequel of nomadic societies which its existence was common in the life of Mongol tribes, but now it has become a semi-permanent aspect and was partially magnificent. Hulagu commanded to build a palace for him in Alatagh and in one of the Armenian histories, it has been mentioned that one of the Armenian princes was sent to a certain area to provide wood for the palace and the other palace was built in the city of Khoy. In the years of Hulagu reigns, buildings in less ephemeral nature initiated, in the same time, for the sake of preserving and exquisite objects of the building, they were fortified. It is said that in the time of Hulagu, a solid high building on an island located in Urmia lake which was seen in the bright summit of a mount in Tabriz. At the same time between the years 1259-1265, Hulagu ordered the construction of an observatory in Maragheh and there is no doubt that this idea was found on the recommendation of Nasir al-Din Tusi as the Persian polymath, architect, philosopher, physician, scientist and theologian in $579-672^{\mathrm{A}-\mathrm{H}}(1201-1274)$, and as one of the prominent personalities and honors of his time. The science, knowledge, actions and the art of this person shows how far the Iranian people have been interested in cultural issues even in the most turbulent periods of history.

Nasir al-Din was in Ismaili religious cult and wrote books on politics, economics and social sciences inspired by Greek resources. In addition, Nasir al-Din had four deputies and some have been come from China to help him. The architectural renewal that began during the reign of Hulagu was slowly, but the structures that were built soon according to their plans, designs, details and decorations were placed as the $13^{\text {th }}$ century buildings. In relation with craftsmen in Il Khānid period, the theory of executing architecture is expressed in three ways: 
1. First, by mostly Iranian craftsmen; since various architectural and construction techniques have been developed in Asia Minor and Iranian craftsmen who have been in those sites and their names have been registered on Anatolia monumental buildings who returned to their homelands after the situation calmed down and the initiation of construction also occurred in their cities and localities.

2. Second, it is probable that the related techniques of Iranian craftsmen from south and center of Iran which were safe from Mongol invasion could continue the progression

3. Third, it is probable that the hereditary of transferring techniques of craftsmen in their family circled during interval times maintained their skill and talent (Wilber, 1955: 9-10).

The cities such as Maragheh, Tabriz, Soltaniyeh, Khorasan are considered as important cities of Il Khānid era in Iran which by having great potentials and significant persons in the government apparatus who were sent or came also to Anatolia as ministers or architects, had great impacts in those times in renewal of architecture and buildings activities and also other issues. By having these capacities, the mentioned cities were chosen also as capitals in Il Khānid period. The table one shows as below the names of some of these persons and their accomplishments.

\begin{tabular}{|c|c|c|c|}
\hline Person & Place of Born & Period & Description \\
\hline $\begin{array}{l}\text { Rashid al-Din } \\
\text { Hamadani }\end{array}$ & $\begin{array}{l}\text { Hamadan } \\
(1247-1318)\end{array}$ & $13^{\text {th }}$ century & $\begin{array}{l}\text { was a statesman, historian and } \\
\text { physician in Il Khānid period, he } \\
\text { was also commissioned by } \\
\text { Ghazan Khan to write the Jāmi } \\
\text { al-Tawārīkh, now considered as } \\
\text { the most important source for the } \\
\text { history of the Il Khānid period } \\
\text { and the Mongol Empire. He was } \\
\text { a prolific author and established } \\
\text { the Rab'-e Rashidi academic } \\
\text { foundation in Tabriz, and the } \\
\text { enormous Soltaniyeh structure in } \\
\text { a complex in Soltaniyeh. }\end{array}$ \\
\hline $\begin{array}{l}\text { Nasir al-Din al- } \\
\text { Tusi }\end{array}$ & $\begin{array}{l}\text { Khorasan-Northern } \\
\text { of Iran (1201-1274) }\end{array}$ & $13^{\text {th }}$ century & $\begin{array}{l}\text { The Persian polymath, architect, } \\
\text { philosopher, physician, scientist } \\
\text { and theologian. He had great } \\
\text { activity through Il Khānid period } \\
\text { and was establisher of Maragheh } \\
\text { observatory. }\end{array}$ \\
\hline $\begin{array}{l}\text { Shams al-Din } \\
\text { Juvayni }\end{array}$ & $\begin{array}{l}\text { Khorasan-Northern } \\
\text { of Iran } \\
\text { (died in 1285) }\end{array}$ & $13^{\text {th }}$ century & $\begin{array}{l}\text { who was vizier and sahib-divan } \\
\text { or minister of finance through } \\
\text { the time of Il Khānids Hulagu, } \\
\text { Abaqa and Tekudar from } 1263 \\
\text { until } 1285 \text {. He had great activity } \\
\text { also in Tabriz. He was also poet, } \\
\text { writer, as one of the famous } \\
\text { ministers of Iran performed the } \\
\text { works through progression of } \\
\text { science, civilization and culture. }\end{array}$ \\
\hline
\end{tabular}




\begin{tabular}{|l|l|l|l|}
\hline $\begin{array}{l}\text { Ata-Malik } \\
\text { Juvayni }\end{array}$ & $\begin{array}{l}\text { Khorasan-Northern } \\
\text { of Iran } \\
(1226-1283)\end{array}$ & $13^{\text {th }}$ century & $\begin{array}{l}\text { Who was the brother of Shams } \\
\text { al-din and was a Persian } \\
\text { historian who wrote an account } \\
\text { of the Mongol Empire entitled } \\
\text { Tarīkh-i Jahān-gushā (History of } \\
\text { the World Conqueror). }\end{array}$ \\
\hline $\begin{array}{l}\text { Badr al-din } \\
\text { Tabrizi }\end{array}$ & Tabriz-Iran & $13^{\text {th }}$ century & $\begin{array}{l}\text { Architect and active scholar in } \\
\text { Konya during the third quarter of } \\
\text { the thirteenth century. He is } \\
\text { described by Aflākī (I, p. 389) as } \\
\text { the architect (me 'mār) of the } \\
\text { tomb of the great mystic poet } \\
\text { Jalāl-al-Dīn Rūmī (d. 1273). He } \\
\text { came to Anatolia as one of those } \\
\text { Iranian craftsmen of learning } \\
\text { who stayed as refuge in Asia } \\
\text { Minor after the Mongol invasion } \\
\text { over Iran in the middle of the } \\
\text { thirteenth century. }\end{array}$ \\
\hline
\end{tabular}

Table 1. The number of people who had great role over $13^{\text {th }}$ century during Il Khānid period

During the reign of Abaqa Khan, the Iranian state administration was gradually returned to Iran, and Shams al-din Juvayni as mentioned before who was poet, writer and as one of the famous ministers of Iran performed also the works through the development of science, civilization and culture. He has been the minister of Il Khānids in the period of Hulagu, Abaqa and Tekudar. He also got the great help of Majd al-Molk who was an important person and full of oversight of the country's financial affairs.

One of the only important construction during Abaqa Khan's period as we know is Takht-e Soleyman which was erected on the remains of Sassanid dynasty. After him in 1282, Sultan Tekudar as the brother of Abaqa Khan and later Arghun Khan as Abaqa's son were chosen. Moreover, Arghun Khan in 1246 had been appointed as the governor of Iran and Il-Chikidai as the commander of the armed forces. The Mongolian language was officially Persian and they were also using Mongolian and Arabic, meanwhile, they also had originality relation with Turkic tribes, so they also were trained by the teachers and scribes of Uygur language. An example of this line is in the French archive as the original name of Arghun Khan who gained the throne after Sultan Ahmed Tekudar. This letter has been written on the scroll by Uygur language and has been done with Chinese seal. At that time, using those kinds of seals was so new in the west and the language has been used was specifically for the Mongols who had been come through Iran.

Arghun Khan showed great importance to the Christians and bishops of the time and many churches were built under the guidance of Rabban Sawma as the church of Marshalita in Maragheh. There are also a lot of writings on the trade and the countries of the west. The Il Khānids tried their most attempt for the encourage of business and this had been one of the basic principles of their policies and they took serious proceedings to increase barter as exchanging of goods and services. Historians have definitely stated that Arghun Khan was interested in building and architecture. In order to know about the works of architecture of that time, we should get help of literary sources beyond other ones. In Tabriz, construction projects were raised and a district by the name of Arghuniya(e) was started by him and was completed at the time of his successors. In Sharuyaz which later called Soltaniyeh- in Zanjan Province today-the construction was also begun. After Arghun, his brother Ghaykhatu reigned with the usual ceremonies for about four years between $690-696^{\text {A.H }}$, and then died. He respected all 
religions, and the brothers of Polo passed through Tabriz during the reign of Ghaykhatu. He accepted Polo brothers kindly and gave them gifts and sent over two hundred riders to protect them to Trabzon. As Marco Polo wrote at the end of his book, the description of the Monarchy of Arghun-GhaykhatuBaidu and Ghazan Khan; It is likely that the Polo brothers stayed for several months at Tabriz. Marco Polo Mentions to Tabriz as a great city with a magnificent and thriving business center (Picture 7.)

In 1295, Baidu Khan came for a short time and after him the golden time of Mahmud Ghazan Khan started. In this while, the southern part of Iran was protected from Mongol attacks and the local Iranian dynasties such as Salghurid family known as Atabeks of Fars, Kharazm Sahs and Muzaffarids retained their authorities to some extent. Being safe from invasion, the south parts of Iran's construction activity continued and could be an example for the construction activities for Northern part of Iran. According to the sources and literature studies Shiraz and Yazd cities have been decorated with beautiful buildings over those years (Wilber, 1955: 5, 11-15).

In October 1297, Ghazan Khan ordered the construction operations in the site of Arghun Khan in Shenb located in the west of Tabriz. History indicates that Ghazan khan had practical information in architecture, natural history, medicine, astronomy and chemistry. He visited the Maragheh observatory several times and ordered for its better construction and development and also one more observatory in Shenb. In history, this can be the first time that be discussed about the attention of a person about particular issues of buildings and arts. Establishing buildings such as monastery for dervishes, college, hospital, splendid fountain, residence for the descendants of the Prophets, splendid garden kiosk during his time mostly occurred in the capitals and efforts were made for keeping all the constructions in a good condition.

In Mahmud Ghazan Khan time, establishment of the charities was one of the things that Ghazan Khan ordered to create for the well-being of everybody. In gardens around each gate of the capital cities and beside important buildings, there were the caravanserais, markets, bathes, so that the merchants entering the city might have all commercial facilities and personal conveniences at hand. Fortunately, information on the administrative affairs of the states and commerce is available. In his time, due to the trade with the countries of the west, two civilizations and two relatively different ways of life by means of west and east civilization had become together. Tabriz as having the major routes for trading and communication, had accommodated venetian merchants and consular offices from Venice to Tabriz and also carrying goods within Caspian Sea too. Ghazan Khan despite the great importance and fanaticism of Islam payed great importance to the Nestorian patriarchs (Wilber, 1955: 16-22). So, as we figured out, as the consequence of Mongolian invasion, the nomadic population starting from 1220s settled down in Mā warā' an-Nahr or Transoxiana in center of Asia (in Persian as Farārūd) began to come to Iran as the center, Anatolia and other territories (Ocak, 1991a: 111). During these migrations, artists, merchants, religious scholars living in the cities and other parts also came to Anatolia. Beside Turkmen masses, Iranians also came to Anatolia in $13^{\text {th }}$ and $14^{\text {th }}$ centuries because of Mongol invasions which later they came back to their countries. Among these people who were artists and architects expressed their arts in Anatolia and after coming back, they also expressed their talents in their countries and local places too. In the Seljuk state of Anatolia which started to lose its power after the Alā ad-Dīn Kayqubād period, the aggravated battle of the reigns in the $13^{\text {th }}$ century led political troubles in regions of Anatolia. By the invasions of Mongols to Anatolia, the lands of architectural part and also related to animals destroyed because of army power and the Mongols who came with their families set up their own villages or settled in Turkmen villages in the fertile areas of central Anatolia (Ocak, 2008c: 369). In the period of Hulagu Khan, when the Seljuk administration in Anatolia became ineffective after the establishment of Il Khānids and in the second quarter of $13^{\text {th }}$ century, economic and political problems in the Seljuk region caused riots by dividing the society (Çetin, 2012: 1207). The destruction of Seljuk cities by Mongol invasions as a result, the city life style comprised nomadic villages in the same time. Since $13^{\text {th }}$ century, the economic situation of people became revival (Akdağ, 1995: 461). In addition, the eastern part of Anatolia was profitable in that time because Tabriz, one of the important capitals of Il Khānid period was a big commercial center and 
most of the taxes collected in Anatolia were provided from the cities near Tabriz such as Sivas, Erzurum, Erzincan, Kayseri and Harput (Picture 6. and Picture 7.).

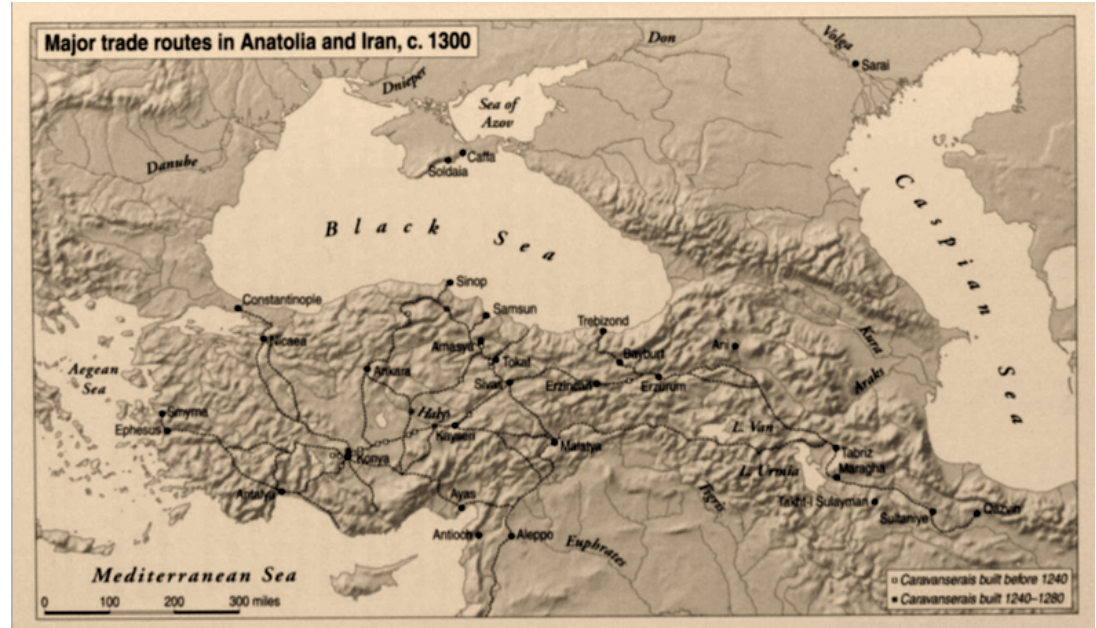

Picture 6. Major Trade Routes in Anatolia and Iran, c. 1300,

Reference: Mediterranean Mapping, Philip Schwartzberg, Blessing, P., 2014: xxi

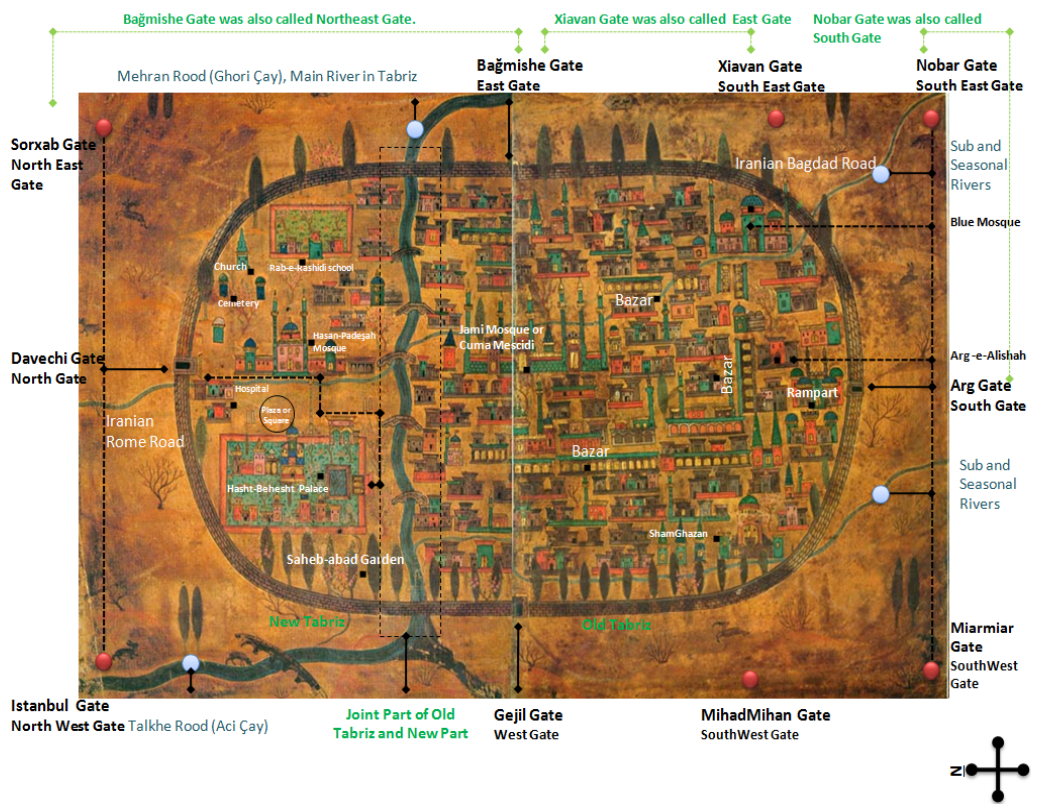

Picture 7. Tabriz City by Nasuh Matrakçi

Reference: Beyani Menazil, translated by R. Reyisnia, 2000: 85-86, Texts \& Signs added by Ghazal Soltani by Adaptation of Old and New Map of Tabriz

Furthermore, in $11^{\text {th }}$ and $12^{\text {th }}$ centuries, the dervishes and Sheikhs who came from Turkestan and Sufis who belonged to different mystic regions had come to Anatolia and settled in important cultural centers such as Konya, Kayseri, Sivas that in result we see the buildings and monuments of Khanqahs (Tekke, Zaviye, Zawiya, Monastery) in these regions (Akarpınar, 2001: 6). Totally, in Il Khānid period, there have been viewed four building types in Iran and Anatolia as:

1. Religious buildings such as Mosques, Khanqahs as the places of prayers and congregations,

2. Schools as the places for teaching Islamic laws and theologies,

3. Tombs as the burial places which also were respected places,

4. Caravanserais as the business center and inn places for a group of people travelling together. 
The culture of Buddhism, Shamanism and Nestorianism founded through building activities were not very effective in building construction. Anatolians were giving importance to the churches and temples but meanwhile, they had left the cultural activities to the Iranian statesmen. In architecture, the construction system of Persians and Seljuks were built during the period of Mahmud Ghazan Khan mostly to the end of Öljaitü khan's period (1295-1335).

With the conquest of all these parts and commencement of Mediterranean trade activities in also western Anatolian coasts, many principalities were established and developed in the region and a commercial revival was taking place (Sümer, 1970a: 75). In this level, caravanserais were important which were seen as best in its function during Il Khānid realm, the evidence of this item was the Il Khānids coins minted in the region in early $14^{\text {th }}$ century and in tax inscriptions applied to monuments (Blessing: 2014) (Picture 8., Picture 9. and Picture 10.).
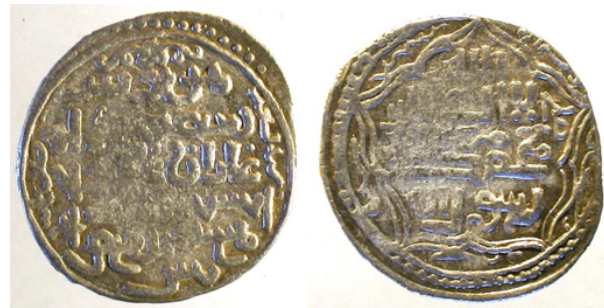

Picture 8. Ghazan Mahmud, AR Dirhem, Tabriz, 699 AH, A-2172

Reference: http://tokakte.dk/ilkhanids.html

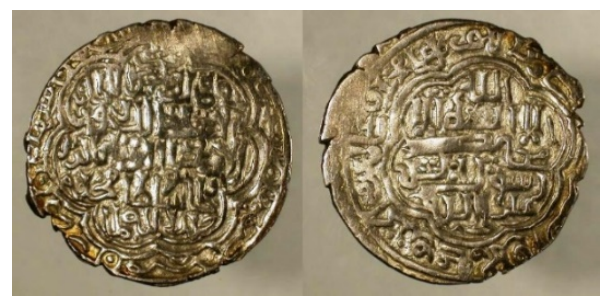

Picture 9. Uljaytu, AR 2-Dirhem, Sultaniya, 71X, A-2180

Reference: http://tokakte.dk/ilkhanids.html

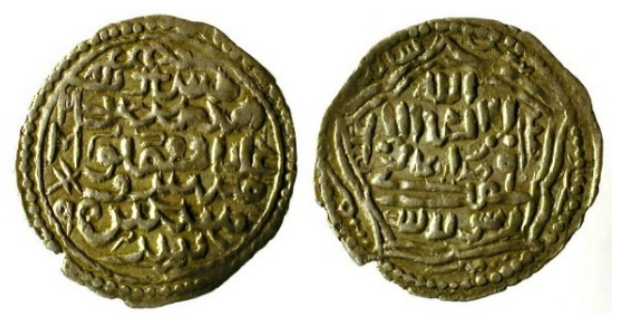

Picture 10. Ghazan Mahmud, AR Dirhem, Arzinjan, 699AH, A-2172

Reference: http://tokakte.dk/ilkhanids.html

\section{CONCLUSION}

As the deduction of previous chapters, searching about the important points happened in communal system of Iran and Anatolia because of the existence of II Khānids through $13^{\text {th }}$ to $14^{\text {th }}$ centuries can be cited here. With Il Khānids settlement in the lands along Iran and Anatolia and their interest for rebuilding and keeping again the humanity safe, an ideology with exhaustive civilization and worldview of Islam occur in their territories and cause the society to receive impacts. Thence, a communal system with its organized, artistic and architectural spaces and their details because of unbreakable bonds with urbanism, people, commerce and their collaborations can have very influential impressions to create a meaningful society even in modern time as we live by using the good ideas and concepts of that time; totally, in this time, creation meaningful objects through a society by existence of historical 
concepts can reimagine the history for people by becoming more clear. Likewise, for the better understanding of the communal system of a dynasty through a period, it is beneficial to get the notes for important characters to make evaluation through them. In fact, these are the precious manuscripts which revealing the qualifications of human's history and make this possibility to know their cultures, arts and interactions. For instance, the devoted letter of Rashid al-Din Fazlullah Hamadani is an example of useful and documentary source to reveal the structure details of Il Khānid era. Moreover, the records of travelers and other historians are admirable; for example, rather than Nasuh Matrakçi which I mentioned in this article, there are the notes about Il Khānids by some more:

1. Ruy González de Clavijo, the Spanish tourist who has reminisced in his notes about some of the monuments in Il Khānids period. He was a Castilian traveler and writer. In 1403-05, Clavijo was the ambassador of Henry III of Castile to the court of Timur, founder and ruler of the Timurid Empire.

2. Hamdullah el-Müstevfî or Hamdullah Kazvini was Iranian historian, geographer and poet. He was living with his family in Qazvin (Kazvin) and they were governing the state by Il Khānids; He has explanations about the monuments.

3. Daulatšāh as-Samarqandī as the noble man of Khorasan city who was the writer and the poet of $15^{\text {th }}$ century $\left(9^{\text {A.H }}\right)$ has great notes about some of the monuments of Il Khānids period in his famous book by the name of "Tazkerat al Shoora".

4. Awhadi Maraghai, the Iranian mystic and writer as poet of $14^{\text {th }}$ century $\left(8^{\text {A.H }}\right)$ by his famous book as Jame Jam, he has very methodical writings about some of the monuments of Il Khānids period.

5. Jean Chardin, the famous tourist of France by having explanations about Tabriz and Rab'-e Rashidi, who traveled to Iran in $17^{\text {th }}$ century (1673).

6. Nader Mirza Afshar the Grandchild of Nader Shah Afshar has also notes about the stability of Tabriz in Il Khānids period.

7. Evliya Çelebi one of leading travelers in Ottoman period who came to Iran in $17^{\text {th }}$ century, has explanations about the capitals and the some of the monuments in Il Khānids period.

8. Nasuh Matrakçi, as one of the greatest persons of Sultan Süleyman in $16^{\text {th }}$ century came to Iran, has a book by name of Beyani Menazil which has valuable notes and photographs explaining about the most capitals of Il Khānids (Keynejad; Belali, 2011).

Furthermore, the layers of information which drive from any aspects of this period from communal system as a part to the whole of it as architectural buildings by means of having written sources in Arabic, Persian, Turkish and etcetera reflect the real appearances of these regions even Anatolia which acted as a frontier one in that time. Therefore, accepting Iran as the central part of Il Khānid realm by comprising important capitals of them and accepting Anatolia which tasted from the time of Byzantine or even before to later by having Islam rules, perform as fundamental cases to suggest the concepts such as their Mobility, Geography and even to be Frontier. In addition, studying about the characters of frontier regions which we confronted here as an Anatolia in Il Khānid period is advantageous because of attractive destination for scholars and craftsmen who came there after Mongol conquest. So, paying attention to the culture of a community that how they are accepted to act as to be centrality and how they are accepted as to be frontier can be discussed in another essay as one of the important result of this article. Political events and cultural linkages between the regions cause stylistic changes, as we here observed the mobility of workshops from one city to another or could happen from one building to another building with craftsmen from various areas which caused the changes because of the existence of patronages in early $13^{\text {th }}$ century too. The case of patronage for workshops was not exclusive only for $13^{\text {th }}$ century, because we observe this kind of patronage in Iran in other periods of dynasties and in Anatolia for example in $16^{\text {th }}$ century in Ottoman empire. Likewise, the possibility of local styles to be fostered in Il Khānid period in the terms of financial, political and workshops which maybe could not be determined as a stylistic style but currently can be also used as a concept of worthwhile method for becoming fostered (Blessing, 2014). 
In a general summary, this period through Il Khānids showed the eligible items in Iran and Anatolia as below:

1. By having good concepts as properties for us and future;

2. As a historical connector between the characteristics of the duration comprising Islam and before it;

3. Considered as a turning point in the regions which had the capability of transferring economical, and cultural issues and performing trading works;

4. Having this ability and meaning for creation city even after the destruction, it can have the notions of utopia;

5. Building functional complexes, paying lot of attention to all sciences and completing architectural activities such as monumental buildings (even in enormous size) and charities beside the help and support of important persons and craftsmen to gather different kinds of people in an immortality ring for gaining optimal activities;

6. The good actions of ministers and patronages in both Iran and Anatolia;

7. The acculturation and adaptation of Il Khānids urbanism and architectural activities with previous rulers of their territories, and also their corresponding with Islamic culture.

And so, the art of Il Khānids was to get the thoughts of the regions which settled in and combined them with indigenous, climatic, regional and cultural needs of the areas to conclude a historical recognition as the major foundation. In these terms, they could keep and continue their traditional way of life by adaptation themselves also with the culture and religion of their new districts. They also payed attention to the characters of their territories and many artifacts, monuments and also communal conditions managed and boosted again. Therefore, this article could be a proper one for the writers to have the basic and fundamental information and helpful consequents through a dynasty that its architectural system will be evaluated in next article.

\section{REFERENCES}

Aigle, Denise. (2008). "Iran under Mongol domination: The effectiveness and failings of a dual administrative system", Bulletin d'études orientales, Supplément LVII 2008 Le pouvoir à l'âge des sultanats dans le Bilād al-Shām. Séminaire IFPO-ACOR, Amman 15-16 mai 2005.

Akdağ, Mustafa. (1995). "Türkiye'nin İktisadi ve İçtimai Tarihi: 1243-1453", C.I, Cem Yayınevi, Istanbul.

Akarpınar, Bahar. (2001). "On üçüncü Yüzyll Anadolu Sahasında 'Aydınlanma Kuşağı'nın Oluşumu", Eskişehir Osman Gazi Üniversitesi Sosyal Bilimler Dergisi, C.II, S.1, Haziran, 5-14.

Aytaç, Nazhan. (2017). "Anadolu'da İlhanlı Mimari Eserleri", Tez Danışmanı: Yrd. Doç. Dr. Nuri seçgin. Türk Islam Sanatları Programı, Mimar Sinan Güzel Sanatlar Üniversitesi.

Blessing, Patricia. (2014). "Rebuilding Anatolia after the Mongol Conquest, Islamic Architecture in the Lands of Rum, 1240-1330", published by Ashghate, Stanford University, USA.

Crane, H. (2011). " Badr-Al-Dīn Tabrīz̄̄", Encyclopaedia Iranica, Originally Published: December 15, 1988, Last Updated: August 22, 2011, This article is available in print. Vol. III, Fasc. 4, p. 382.

Çetin, Halil. (2012). "İlhanlı Hâkimiyeti Altında Anadolu'da Siyasetin Temel Dinamiği: Göçebe Moğol-Türkmen Çatışması", Turkish Studies-International Periodical for the Languages, Literature and History of Turkish or Turkic, Volume7/4, Ankara, 1203-1216.

Deniz, Arda. (2013). "Moğolların Anadolu Politikası ve İlhanlılar Devleti Tarihi", Ekim Yayınları, Istanbul.

Erdem, İlhan. (2003 b). "Türkiye Selçuklu-İlhanlı İktisadi, Ticari İlişkileri ve Sonuçları", Ankara Üniversitesi Dil ve Tarih Coğrafya Fakültesi Tarih Bölümü Tarih Araştırmaları Dergisi, C.XXI, S.33, 49-67.

Judith, G. Kolbas. (2006). "The Mongols in Iran: Chingiz Khan to Uljaytu 1220-1309", Routledge, Taylor and Francis Group, London and New York, Simultaneously published in the USA and Canada by Routledge.

Kaynejad, Muhammad. Ali.; Belali Oskui, Azita. (2011). "Imaginary recreation of Rab'-e Rashidi based on historical texts", The Institute for the Translation and Publication of Textural Works, Tehran, Iran.

Submit Date: 10.01.2019, Acceptance Date: 25.03.2019, DOI NO: 10.7456/10902100/009 
Mortazavi, Manochehr. (1964). "Religious in Il Khānids Period", Journal of Literature Faculty, University of Tabriz.

Ocak, Ahmet Yaşar. (1991a). "Anadolu'nun Türkleşmesi ve İslamlaşması", TDV İslam Ansiklopedisi, C.III, 110-116.

Ocak, Ahmet Yaşar. (2008c). "Social, Culturel and Intellectual Life 1071-1453", The Cambridge History of Turkey, IV, Cambridge University Press, 353-422, Cambridge.

Özgüdenli, Osman Gazi. (2005). "Moğollar", TDV İslam Ansiklopedisi, C.XXX, 225-229.

Sevim, Ali. (1988). "Anadolu'nun Fethi Selçuklular Dönemi: Başlangıcından 1086'ya kadar", Türk Tarih Kurumu Yayıları, Ankara.

Sümer, Faruk. (1970 a). "Anadolu'da Moğollar", Selçuklu Araştırmaları Dergisi, S.I, 1147.

Üremiş, Ali. (2005). "Türkiye Selçuklularının Doğu Anadolu Politikası", Babil Yayınları, Ankara.

Wilber, Donald. N. (1969). "The Architecture of Islamic Iran, the IL-Khanid Period", NewYork: Greenwood Press. 